\title{
Evaluating the Competitiveness of Intercity Buses in Terms of Sustainability Indicators
}

\author{
Mintesnot Woldeamanuel \\ California State University Northridge
}

\begin{abstract}
A sustainable transportation system is the one that is designed based on environmental awareness, social equity, and economic opportunities. Public transportation, in general, and intercity transit, in particular, are playing very significant roles for communities to reach their sustainability goals. Of the available intercity transit services, buses are showing a noteworthy growth to be a competitive mode in terms of sustainability indicators. After several decades of decline, intercity bus services are growing at an increasing rate, overtaking other intercity services. This paper, based on data from various sources and existing literature, makes a comparative analysis of intercity bus services with its competitors, mainly train transit (Amtrak) and air services. The analysis result shows that intercity buses are standing out to be an environmentally-friendly, economically-viable, and socially-inclusive mode of long-distance travel (especially to rural and small communities and for persons with no car).
\end{abstract}

\section{Introduction}

Intercity buses, as defined by the Federal Transit Administration, are regularlyscheduled bus services for the public that operate with limited stops over fixed routes connecting two or more urban areas not in close proximity, and that make 
meaningful connections with scheduled intercity bus service to more distant points, if such service is available (FTA 2007; Kack et al. 2011). The KFH Group, a transit consultancy group, broadly includes services provided by private for-profit firms and services provided by public transit grant recipients that have a "meaningful" connection to the network. A "meaningful connection" has generally been defined by the KFH Group as a connection with a wait time of less than two hours (KFH Group 2007).

In whatever way it is understood, intercity bus transportation has seen growing usage in rural areas and smaller communities as part of the public transportation network. Intercity buses link smaller communities within a region and also link rural communities to larger urban areas. The industry is also known to provide service for communities where access to car ownership is limited. Although U.S. cities lost a significant amount of their scheduled intercity service over the last several decades, recently, the industry is experiencing noteworthy growth. Despite this recent growth, intercity bus services are having this success without public subsidy, unlike Amtrak, municipal transit systems, and a few specialized programs that receive federal or state assistance. Services rely on passenger fare revenue to cover operating and capital costs and to generate an adequate return on investment to attract capital for growth (Fravel 2003).

Several research papers and policy documents suggest that intercity buses are the environmentally-friendly, economically-viable, socially-acceptable and safe means of long-distance travel when compared to other intercity modes of travel. Thus, this paper aims to discuss the sustainability aspect (in terms of social, economic, and environmental indicators) of intercity buses in comparison with other intercity modes of travel. The data are gathered from various sources and existing research and policy documents. The Intermodal Passenger Connectivity Database (IPCD) and other data from the Bureau of Transportation Statistics (BTS) are used for analyzing the geographic coverage of intercity transportation. The IPCD is a nationwide data table of passenger transportation terminals, with data on the availability of connections among the various scheduled public transportation modes at each facility. In addition to geographic data for each terminal, the data elements describe the availability of rail, air, bus, transit, and ferry services. These data have been collected from various public sources to provide the nationwide measurement of the degree of connectivity available in the national passenger transportation system. Secondary data were gathered from various sources and analyzed to make a sound comparison between intercity buses and other long-distance travel modes using pre-defined sustainability indicators. 


\section{Background of Intercity Buses}

\section{Historical Background}

Historical accounts suggest that scheduled intercity bus service began in 1913 when passengers were carried between the towns of Hibbing and Alice in northern Minnesota (Wrenick 2011). By 1926, there were 4,040 intercity bus industries nationwide offering scheduled bus service for passengers traveling between cities (Damuth 2008). As documented by Schwieterman et al. (2007), the intercity bus sector slumped in the 1960s in response to the decline of central cities, improvements to other modes of transportation (especially personal automobile), and increases in household incomes. By the mid-1970s, the number of passengers using scheduled bus services was falling sharply, and the industry's image was fast deteriorating (Schwieterman et al. 2007). U.S. cities lost nearly one-third of their scheduled intercity service between 1960 and 1980, with more than half of the remaining services being lost between 1980 and early 2006 (Figure 1). However, by late 2007, the sector was going through a significant rebirth and was expanding at the fastest rate in more than 40 years. Today, as documented by O'Toole (2011) and Schwieterman et al. (2007), growth by low-cost carriers such as Megabus and the renewed strength of Greyhound and other conventional lines suggests that there is a noticeable increase in demand (O'Toole 2011; Schwieterman et al. 2007). Consequently, the efficiency of airports and rail stations is being enhanced by intermodal connecting service provided by intercity bus operators. In 2007, 3.4 percent of the intercity bus miles were airport shuttle service miles (Damuth 2008).

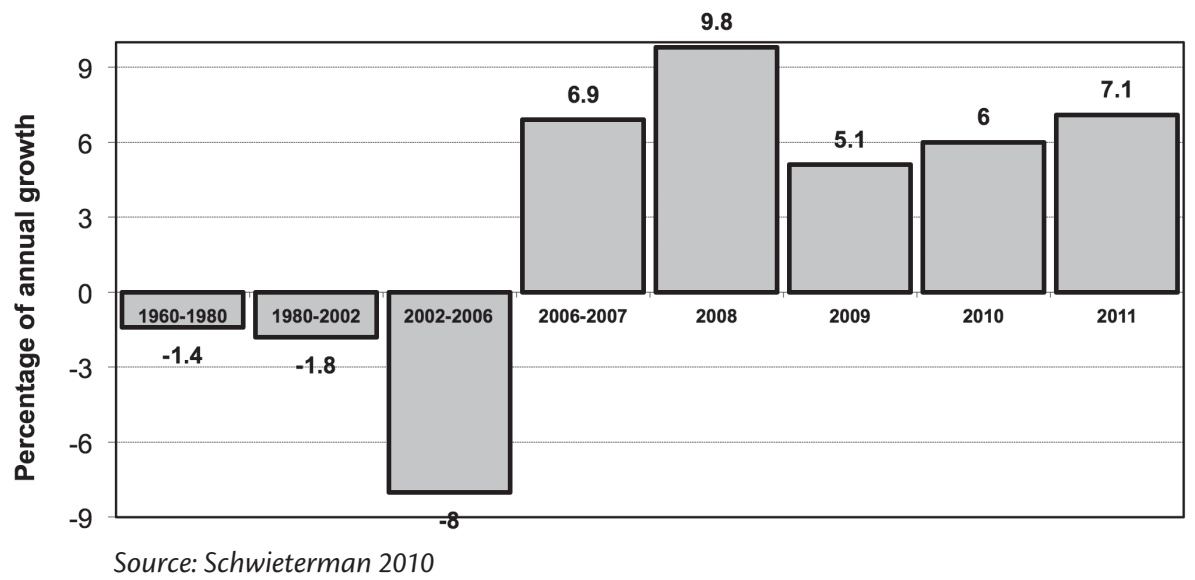

Figure 1. Percentage annual growth and decline of intercity bus service 


\section{Current State}

According to a report by Nathan, Inc., intercity buses provided 751 million passengertrips in 2007, 9 percent more than the number of U.S. certificated commercial air carriers and almost 2 times more than Amtrak and commuter rail combined (Figure 2). Nationally, locations served by intercity buses include more than five times the number of airports and intercity rail stations (Figures 3 and 4). Also, according to Figure 4(a), produced from the Intermodal Passenger Connectivity Database (IPCD), the intercity buses offer a flexible service to more distributed locations in a given city. In that way, the intercity bus industry is known in its coverage of rural communities. Intercity buses cover 89 percent of rural residents, while air service covers 70 percent and intercity rail covers only 42 percent. For 14.4 million rural residents, intercity buses are the only available mode of intercity commercial transportation service (IPCD; BTS; Damuth 2008).
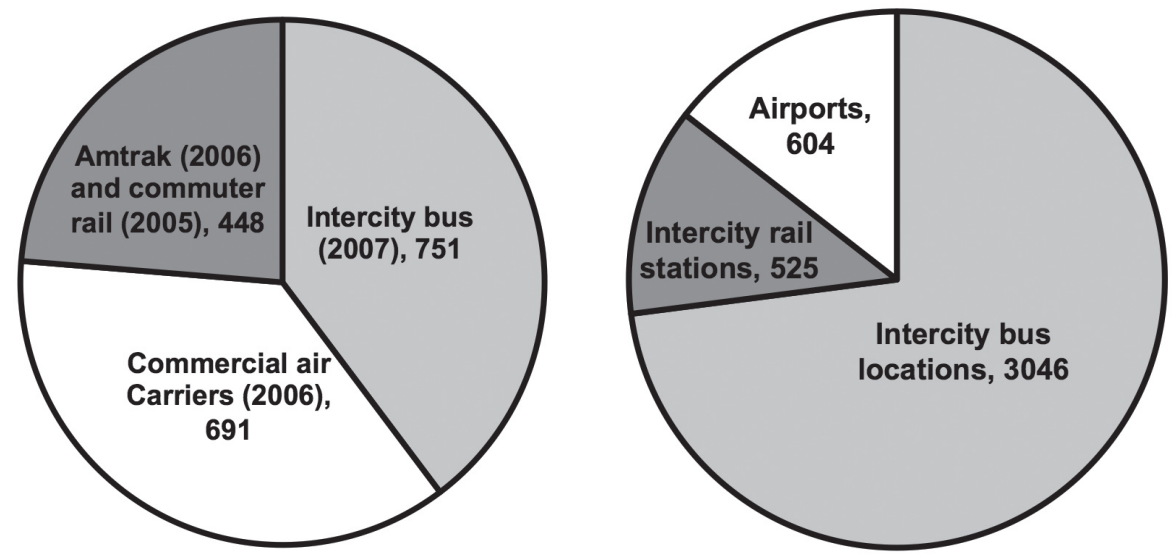

Source: Motorcoach Census 2008

Figure 2. Passenger trips (in millions)
Figure 3. Number of intercity facilities

The intercity bus was the only intercity mode to grow significantly in 2011, making it the fastest-growing form of intercity transportation for the fourth year in a row. This marks the fourth consecutive year that scheduled bus service grew faster than other modes of intercity transportation (McKonne 2011).

According to a recent report from DePaul University on intercity transportation (Schwieterman et al. 2011), rising awareness of new services, escalating fuel costs, and a modest economic recovery during the latter part of the year 2011 allowed the intercity bus industry to accelerate its rate of growth in 2011. The report also noted that curbside operators, most notably BoltBus and Megabus, introduced a number 
of new routes in 2011, while Greyhound expanded its premium "Express" service. This expansion, coupled with increased marketing efforts, led to heightened brand recognition and a growing public acceptance of bus travel (Schwieterman et al. 2011). Curbside operators in 2011 account for 778 daily bus operations in the continental United States, up from 589 a year before. The significant growth of curbside services was attributed primarily to the creation of three new hubs and incremental expansion from established hubs. Curbside operators, which avoid traditional stations in favor of curbside pickup while emphasizing Internet ticketing and express service between major cities, have been one of the country's fastest-growing intercity transportation sectors in recent years (Klein 2011; Schwieterman et al. 2011).
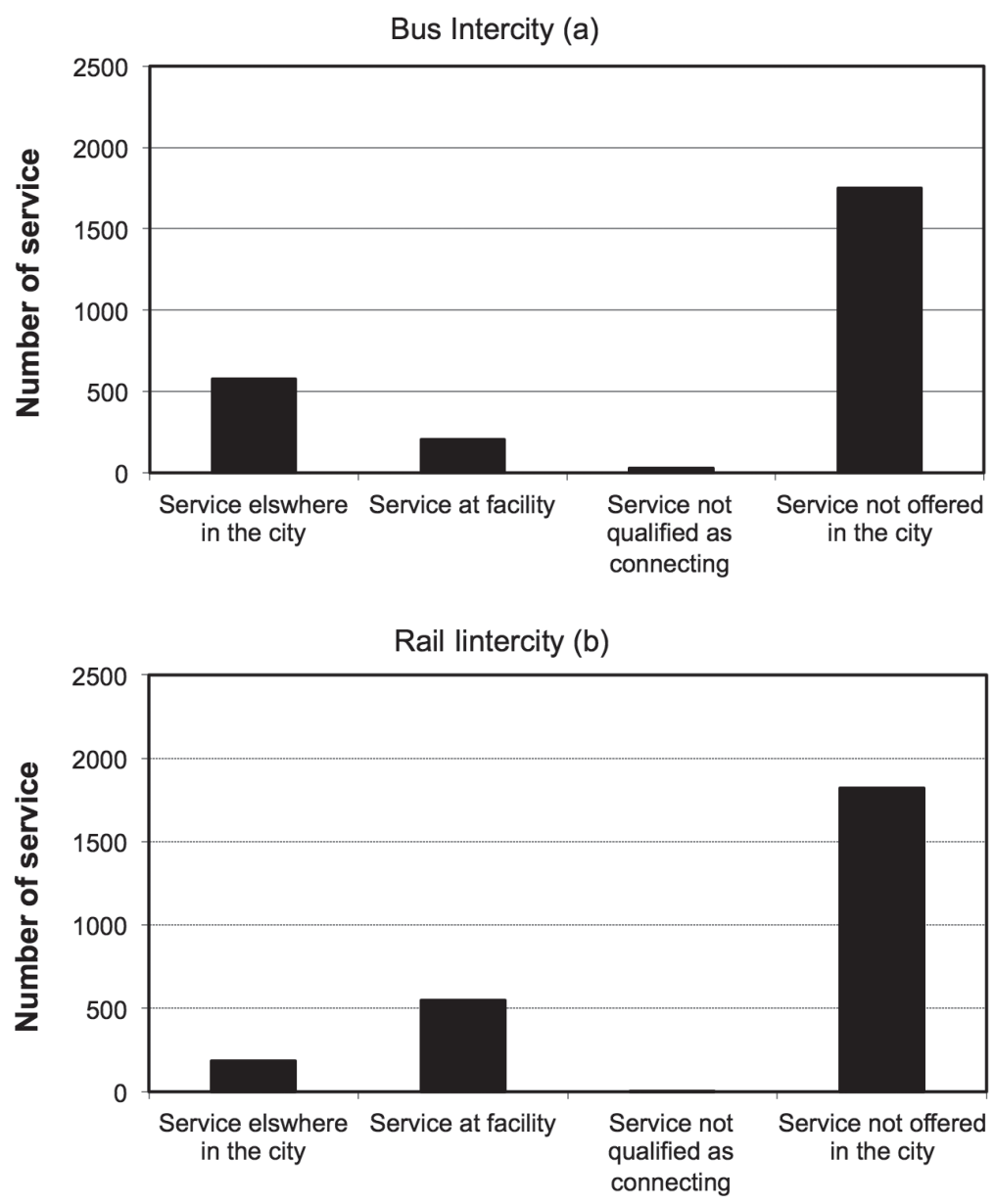

Figure 4. Intercity transit facilities 

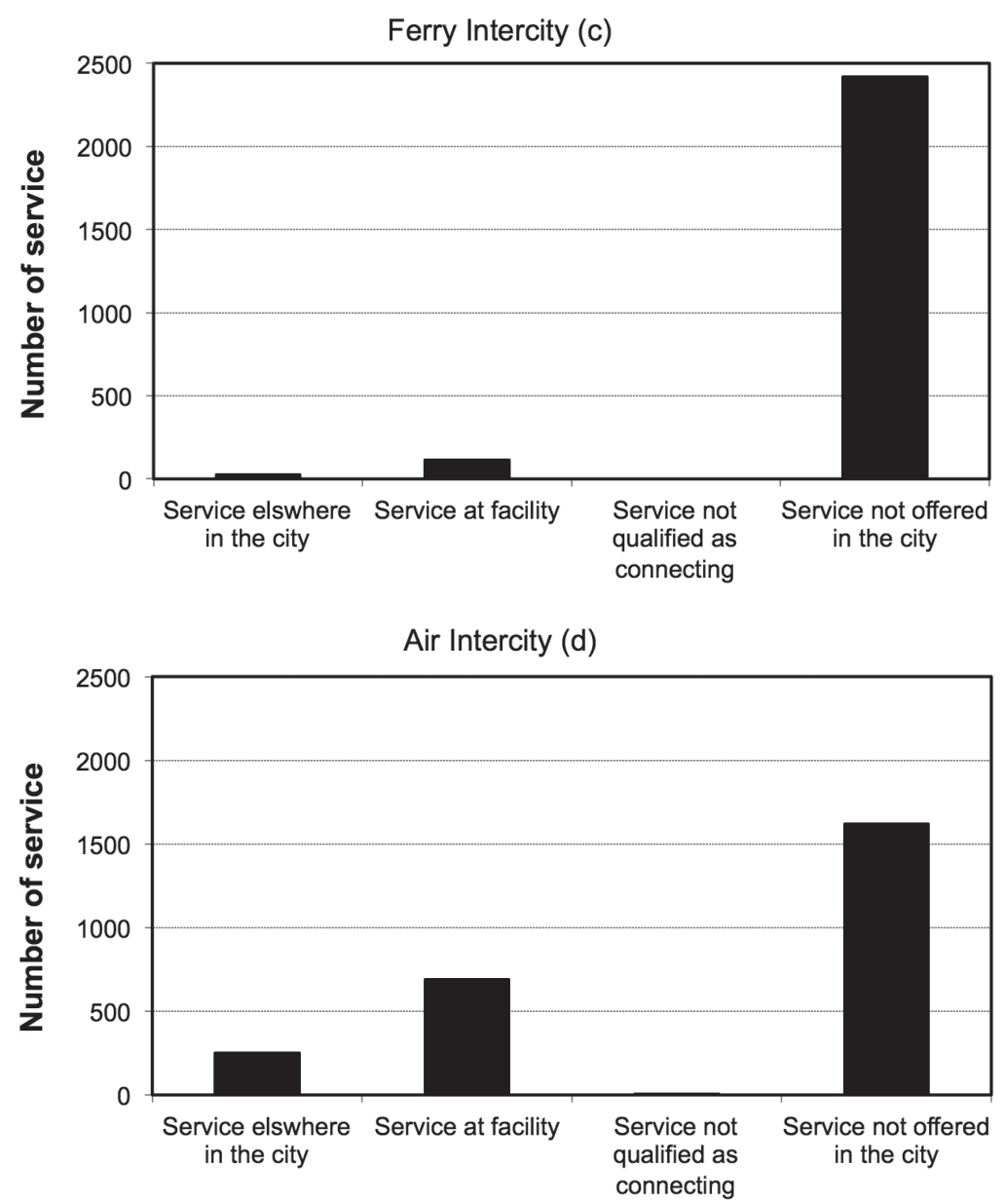

Source: The Intermodal Passenger Connectivity Database (IPCD), BTS 2012

Figure 4 (continued). Intercity transit facilities

\section{Sustainability Indicators}

Sustainable communities are those that can provide opportunities to a viable economy, environmental protection, and social equity. Most literature on sustainability generally agrees that the whole idea of sustainability could be based on three components: the three E's: economic, environment, and equity. In the following section of this paper, the three E's are used to analyze the competitiveness of intercity bus in comparison with other intercity modes of travel. 


\section{Economic Indicators}

The economic argument for intercity bus service emanates from the fact that the intercity bus industry is a least-subsidized mode while generating revenue and supporting the creation of new jobs. In 2007, ticket sales to tourists and spending on new intercity buses generated $\$ 55$ billion in sales, which supported 792,700 jobs (Bourquin 2008; Bureau of Economic Analysis). Generally, consumer and industry spending stimulates local economies, thus promoting economic growth and opportunity. For example, according to a report from Guerrilla Economics, LLC, in West Virginia (2008), \$40.3 million in spending, 1,300 jobs, and \$4.0 million in state and local tax revenues were attributable to intercity bus charter and tour visitors in 2006. In southwestern Pennsylvania, $\$ 39.2$ million in spending, 1,030 jobs, and $\$ 4.2$ million in taxes were due to intercity bus charter and tour visitors in 2006. In Sevier County, Tennessee (the Pigeon Forge area), \$89.2 million in spending, 2,100 jobs, and $\$ 8.9$ million in taxes were due to intercity bus charter and tour services in 2005. These are just three of hundreds of regions throughout the country where local economies benefited from visitors who traveled by intercity bus (Guerrilla Economics, LLC 2007a; Guerrilla Economics, LLC 2007b; Damuth 2008).

It is undeniable that other intercity transport services (rail and air) also contribute to the local and regional economies a great deal. However, the distinction between intercity buses and other long-distance travel modes is that intercity buses' economic contributions come at virtually no cost to the government. Unlike other transportation industries, the intercity bus industry has received no federal subsidy. According to recently-published documents, from 1996 through 2005, public transit and commercial air passenger transportation received nearly all the subsidy. However, Amtrak received the highest subsidy per passenger trip and passenger mile. From 1996 through 2005, the intercity bus industry received just $\$ 0.06$ of federal subsidy per passenger trip. In contrast, public transit received nearly 13 times more, commercial air carriers received 72 times more, and Amtrak received nearly 800 times more subsidy than the intercity bus industry (Figure 5) (O'Toole 2011; Damuth 2008). 


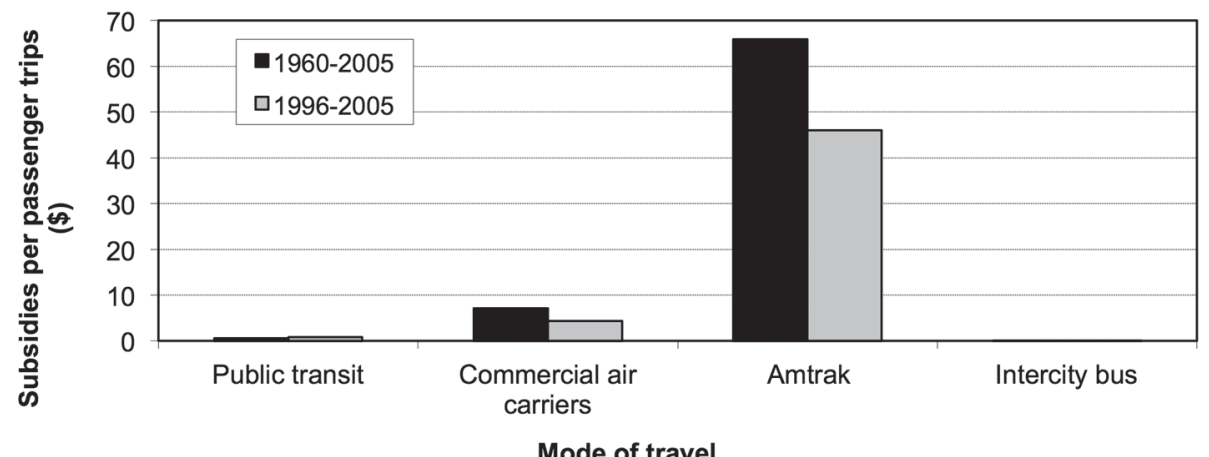

Source: Nathan Associates, Inc., 2008

\section{Figure 5. Subsidies per passenger trips (2005 dollars)}

\section{Environmental Indicators}

Another measurement of sustainability is the benefit of a mode of travel in terms of its contribution to environmental protection. Many studies agree that intercity buses are an environmentally-friendly mode of transportation. Intercity bus passenger miles per gallon of fuel are more than twice the fuel efficiency of commuter and intercity rail and more than four times greater than domestic air carriers and transit buses (Figure 6). Intercity bus emission of $\mathrm{CO} 2$ gases, linked to global warming, are lower than any other modes. Other modes produce three to four times more emissions (Figure 8) (M. J. Bradley \& Associates 2008). O'Toole (2001), citing from Transportation for Tomorrow, stated that intercity buses use less than 1,000 British Thermal Units (BTUs) per passenger mile, while intercity passenger trains use more than 2,500. Also, diesel-powered Amtrak trains produce roughly 2.5 times as much carbon emis $\neg$ sions as intercity buses (O'Toole 2011).

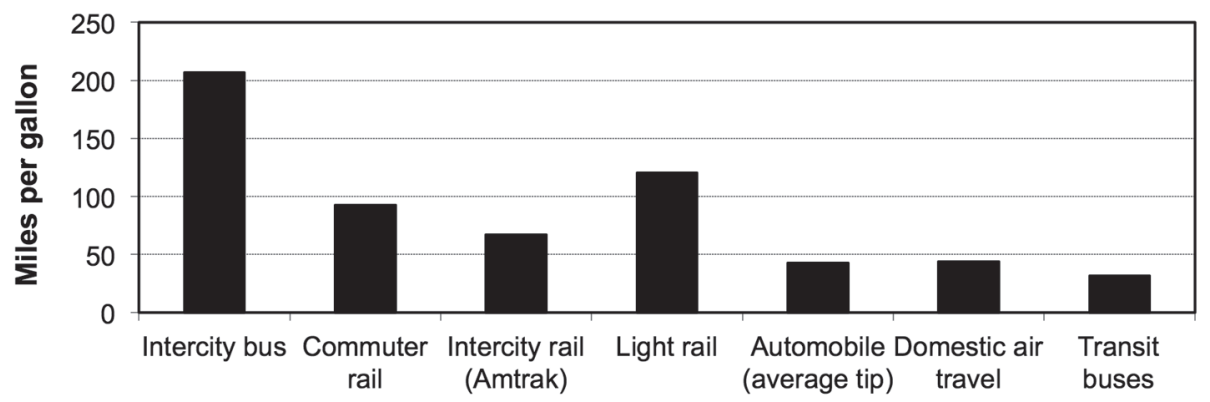

Mode of travel

Figure 6. Passenger miles per gallon 


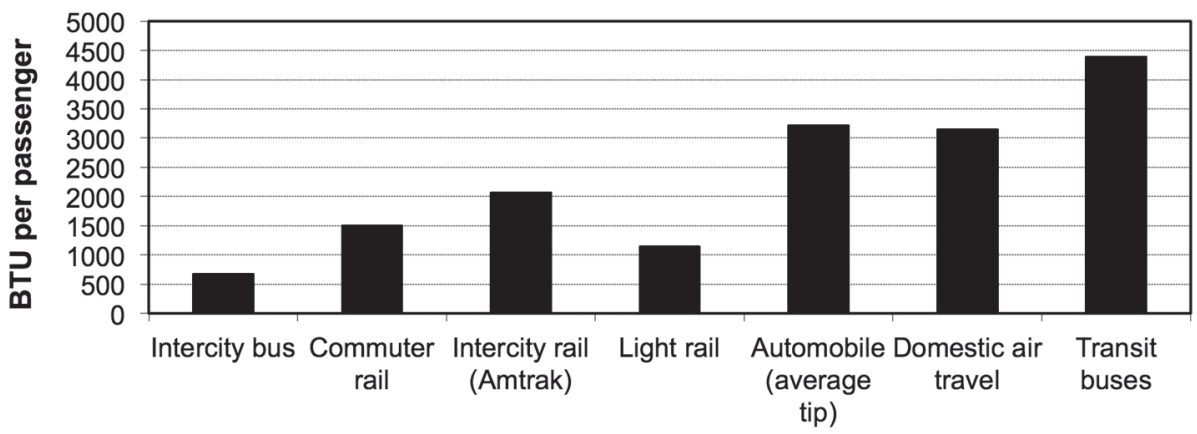

Mode of travel

Figure 7. BTUs (British Thermal Units) per passenger mile

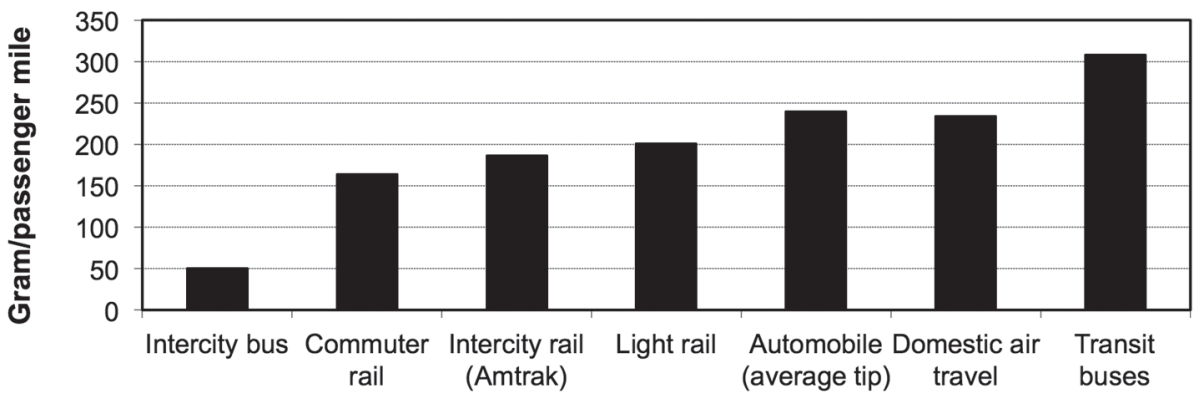

Mode of travel

Figure 8. Carbon dioxide emissions (gram per passenger mile)

\section{Equity Indicators}

\section{Rural Coverage}

Rural communities can be disadvantaged by the transportation system due to their distant proximity from urban areas where the transportation services are concentrated. Intercity bus provides scheduled intercity services to many rural and small town communities (in many cases, the only service for those communities) (Bureau of Transportation Statistics 2005). Intercity bus transportation provides a particularly critical service for smaller communities in which air or passenger rail travel options are not available. It also provides a transportation option that may be more affordable than air or rail, when these are available, which is significant for many residents in rural areas (Transportation Research Board 2002). 
Figures 9 and 10 show the percentage of rural population covered by each mode for all the 50 states combined (Bureau of Transportation Statistics 2005). Also, a map created based on the Intermodal Passenger Connectivity Database shows that intercity buses have a deeper penetration to rural areas than rail transit (Figure 11).
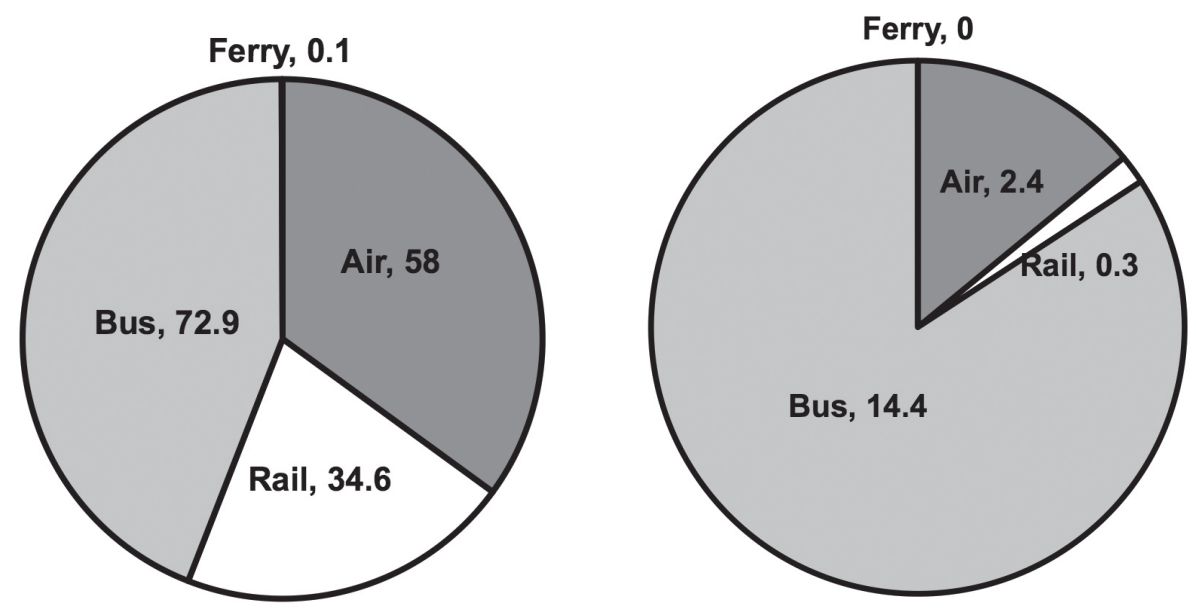

Source: BTS 2005

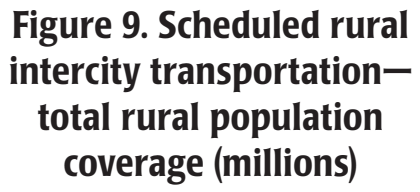

Figure 10. Scheduled rural intercity transportationsole mode for rural population (millions)

Generally speaking, intercity bus has the deepest penetration within rural America. Figures 12-14 show the numbers of rural residents living within a reach of a particular intercity mode. Figure 12 shows that there are many rural residents living within intercity bus service areas, and Figures 13 and 14 show that only few rural residents have access to rail and transit services. The intercity bus network covers 88.5 percent of the total U.S. rural population and 89 percent of the rural population in the 48 contiguous states. (Some state governments provide funds for intercity bus services through the Federal Transit Administration Section 5311(f) formula grants program.) In most states, intercity buses serve a greater share of the rural population than the other modes. The only exceptions are in several Northeast states where air or rail service covers a slightly higher percentage of the population and in Alaska where air service has much deeper penetration of rural areas (Figures 12-14). 


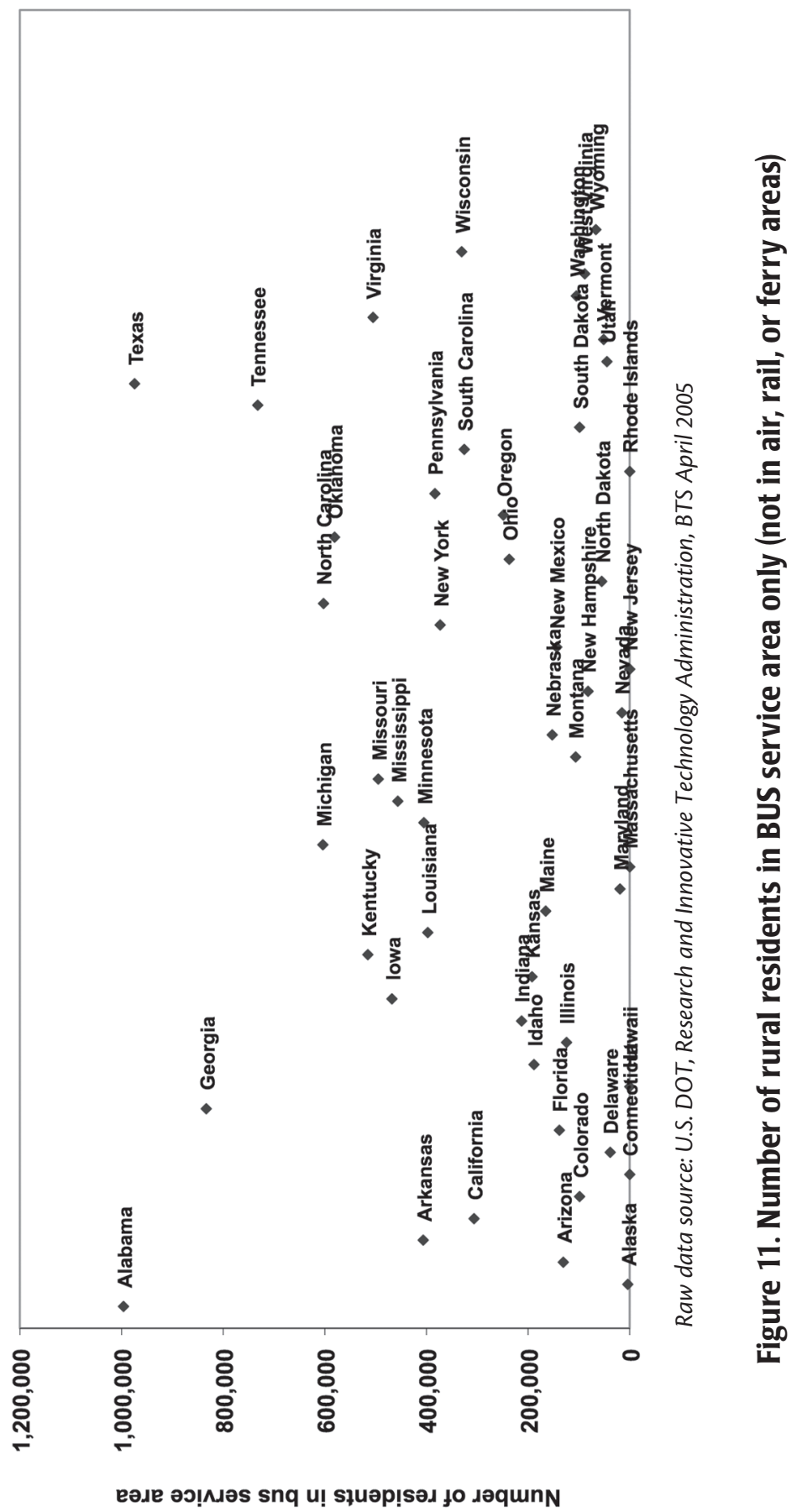




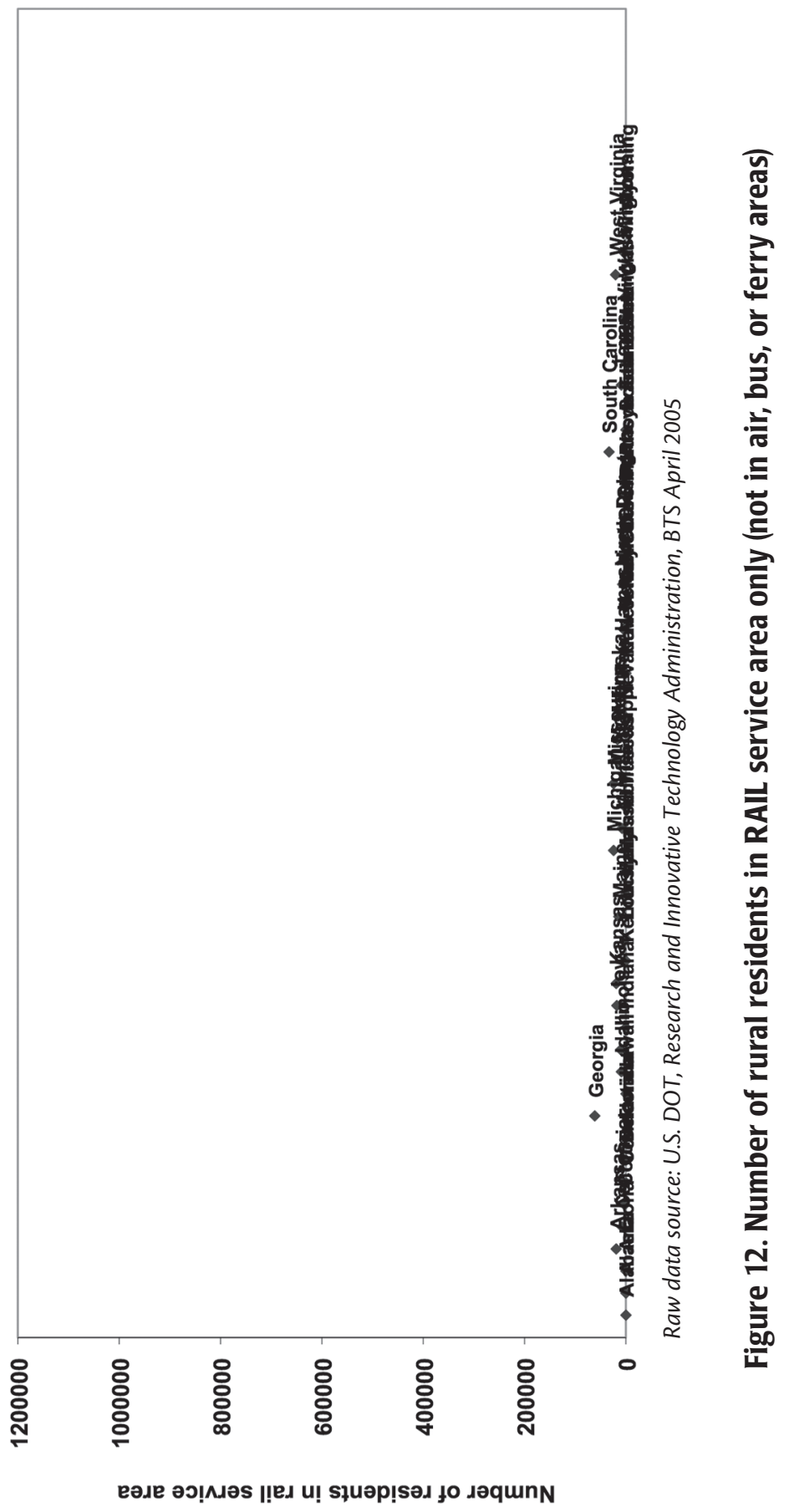




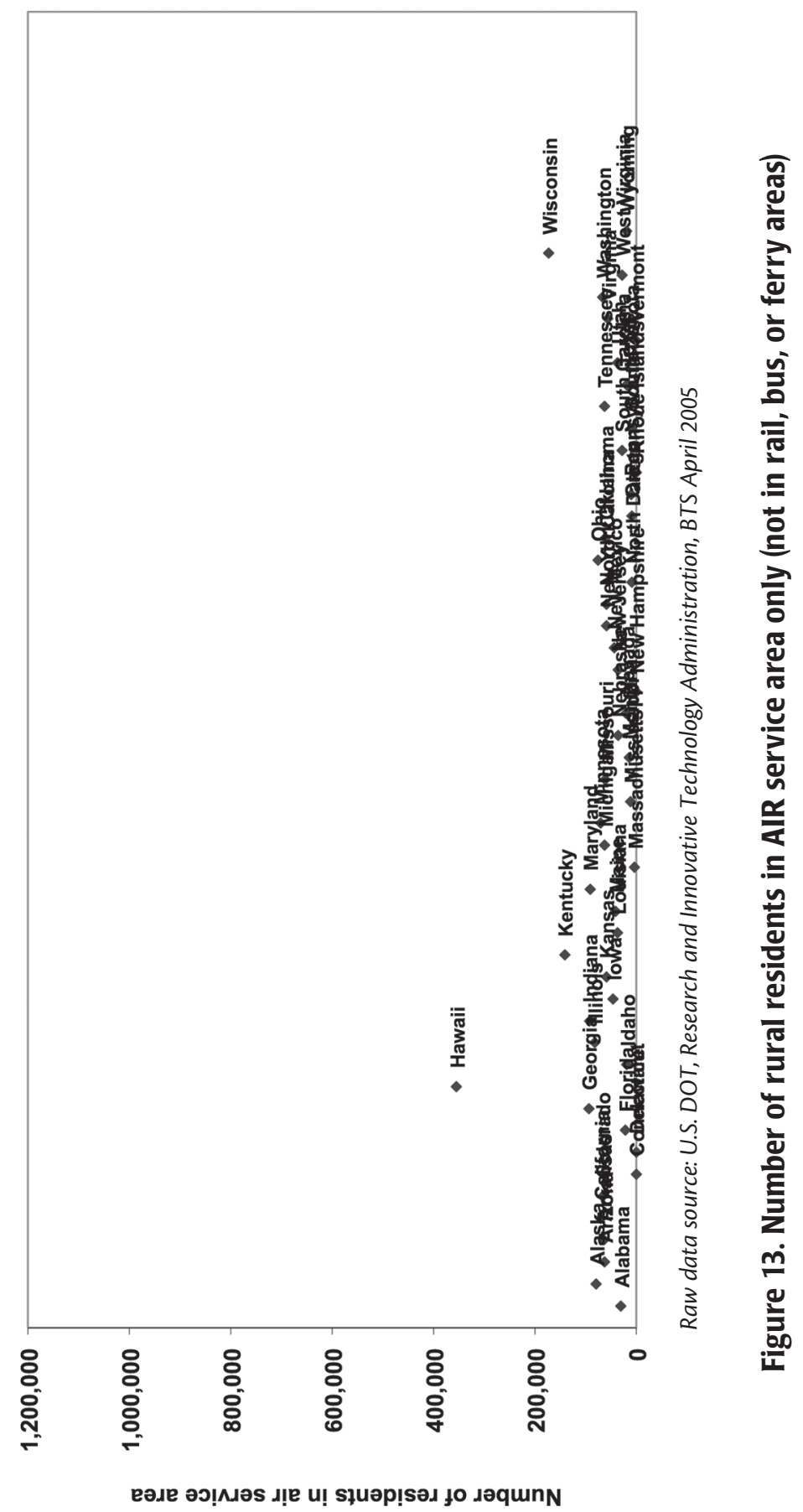



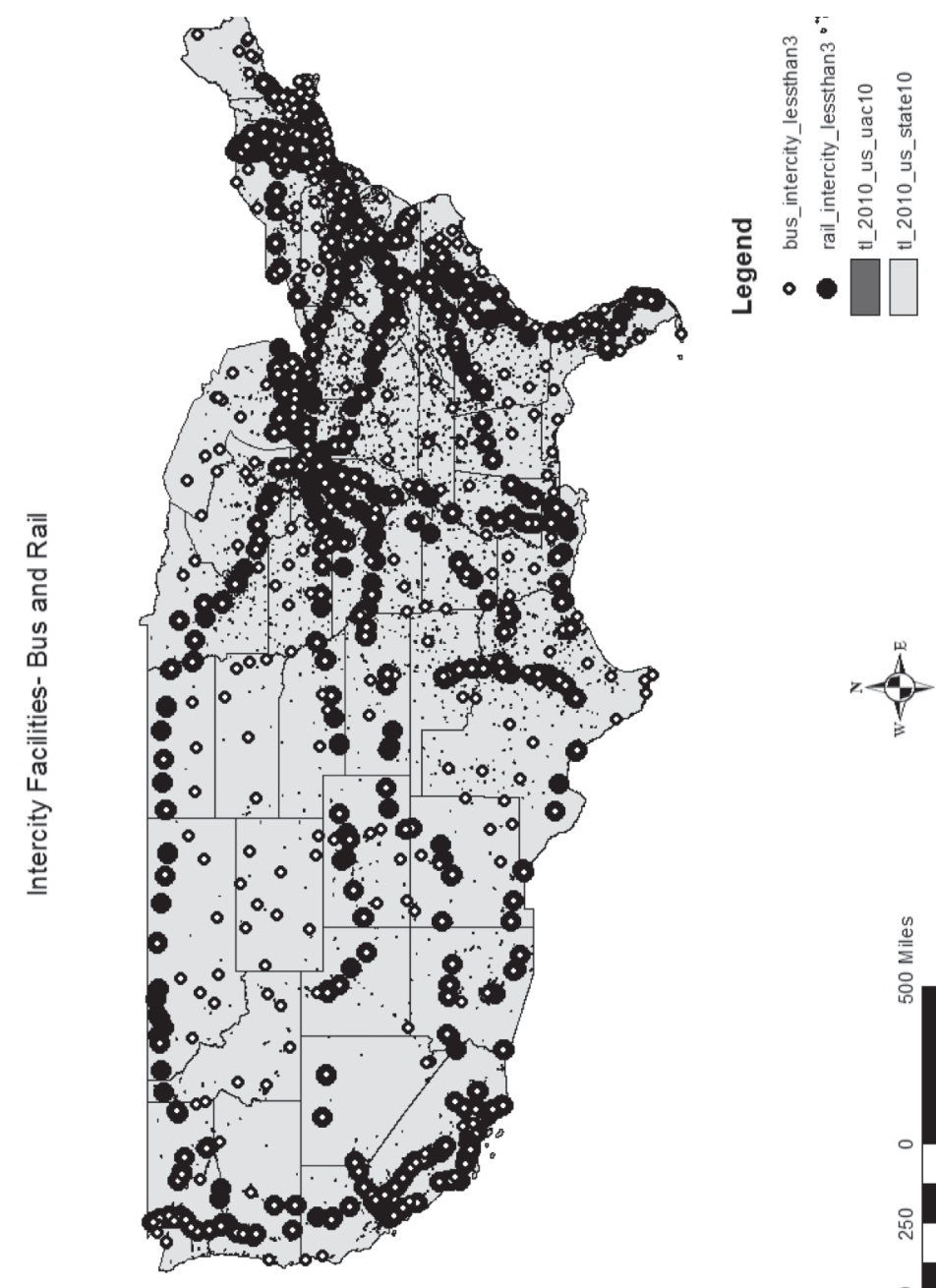
The intercity bus industry covers 100 percent of the rural population in 2 states, over 90 percent in an additional 20 states, and over 80 percent in another 10 states. There are only 4 mainland states where less than 70 percent of the rural population has intercity bus access, but even in these states, bus covers more of the population than the other modes (Table 1 and Figures 11-14). Approximately one in five rural residents who have access to intercity transportation (16.4 million) is within the coverage area of only a single intercity mode. For most of those people (13.5 million), intercity bus provides the sole access to commercial intercity transportation (BTS 2005).

\section{Table 1. Scheduled Rural Intercity Transportation Coverage by Mode}

\begin{tabular}{|l|c|c|c|c|}
\hline \multirow{2}{*}{ Percent of Rural Population Covered } & \multicolumn{5}{|c|}{ Number of States } \\
\cline { 2 - 6 } & Air & Rail & Bus & Ferry \\
\hline $100 \%$ of rural population & 4 & 1 & 2 & 0 \\
\hline $90-99 \%$ of rural population & 3 & 1 & 20 & 0 \\
\hline $80-89 \%$ of rural population & 8 & 1 & 10 & 0 \\
\hline $70-79 \%$ of rural population & 7 & 3 & 12 & 0 \\
\hline $60-69 \%$ of rural population & 13 & 5 & 1 & 0 \\
\hline $50-59 \%$ of rural population & 7 & 3 & 3 & 0 \\
\hline $40-49 \%$ of rural population & 5 & 9 & 1 & 0 \\
\hline $30-39 \%$ of rural population & 3 & 8 & 0 & 0 \\
\hline $20-29 \%$ of rural population & 0 & 11 & 0 & 0 \\
\hline $1-19 \%$ of rural population & 0 & 5 & 0 & 2 \\
\hline No coverage of rural population & 0 & 3 & 1 & 48 \\
\hline
\end{tabular}

Source: BTS, 2005

Intercity buses also offer low fares and travel options for persons without personal vehicle. Intercity bus passengers tend to be more transit-dependent than passengers of other intercity modes. Data from the Bureau of Transportation Statistics' American Travel Survey of 1995 show that regular intercity bus riders are more likely to be under 24 years old or over 60 years old than travelers on other modes. They are also more likely to have lower household incomes than those using other intercity modes and less likely to have a vehicle (Fravel 2003).

Intercity buses provide affordable transportation service, extending opportunities to the broader community. Over half (54.2\%) of all long-distance intercity bus passenger trips and one-third (33.1\%) of all long-distance charter or tour bus trips are taken by households with annual incomes less than $\$ 25,000$. In contrast, only 9.7 
percent of commercial airplane trips are taken by households with annual incomes less than $\$ 25,000$. Nearly two-thirds (65.5\%) are taken by households with annual incomes exceeding $\$ 50,000$ (Figures 15 and 16) (Damuth 2008).

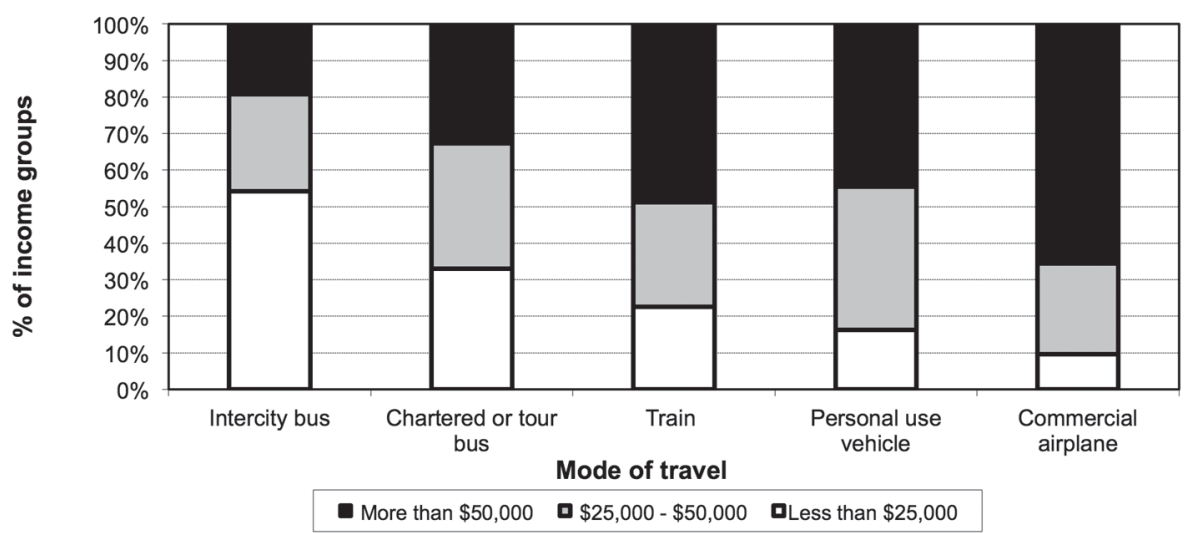

Source: 1995 American Travel Survey, BTS, U.S. DOT, October 1997

\section{Figure 15. Distribution of long-distance trips by mode and annual household income}

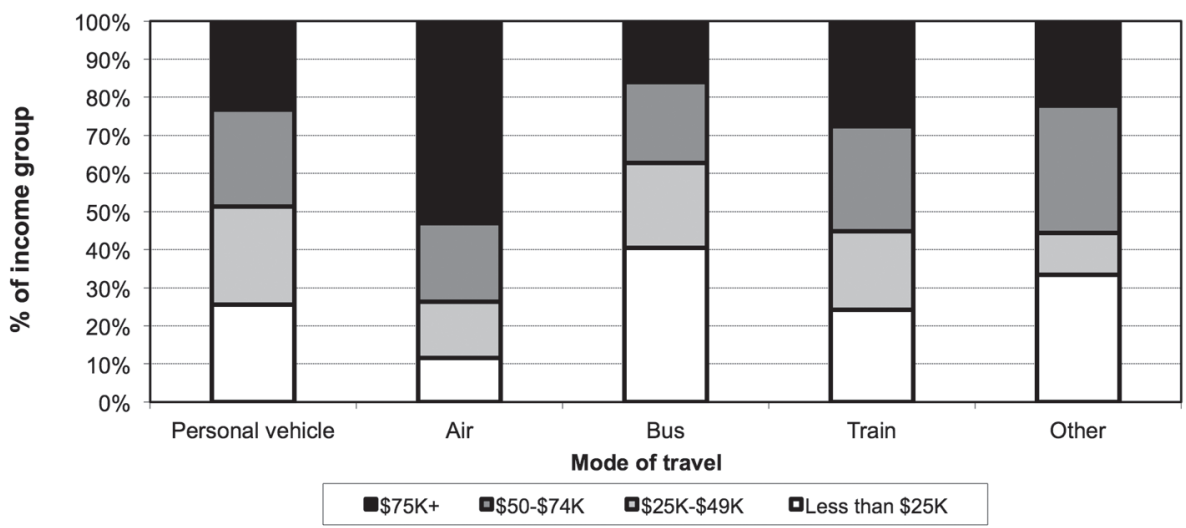

Source: U.S. DOT, BTS

\section{Figure 16. Long distance trips by mode for household income groups}

\section{Safety}

Social sustainability concerns with the basic needs and a good quality of life for all members of the community. Safety is one measure of quality of life. To this end, research indicates that intercity buses are a safe mode of transportation. According 
to Damuth (2008), among all passenger transportation modes, the intercity bus fatality rate is the lowest ( 0.5 fatality per 100 million vehicle miles). For passenger cars, the fatality rate is more than twice as high, and for U.S. air carriers, the fatality rate is nearly three times higher. For passenger trains, the fatality rate is nearly 16 times higher than the rate for intercity buses. Intercity buses suffer almost 80 percent fewer fatalities per billion passenger miles than Amtrak. From 1999 to 2008, intercity buses suffered 0.3 passenger fatalities per billion passenger miles, compared with 1.4 for Amtrak and 1.1 for urban transit buses (Damuth 2008).

\section{Summary and Conclusion}

Intercity bus services are an integral part of the overall surface public transportation system that meets long-distance travel demand. The industry has enjoyed a recent increase in ridership and a wide recognition by the public. It is playing a vital role in connecting major cities with each other and with rural and small-town communities. A review of literature and data analysis in this study shows that intercity buses are not only the fastest-growing industry but also a prominent mode in terms of sustainability indicators (as it is summarized in Table 2). Intercity buses are helping communities reach sustainability goals. Although other intercity transportation modes are playing undeniably significant role in catering a long-distance travel demand, the recent surge of intercity buses spark a renewed interest in its competitiveness in terms of sustainability indicators.

With the percentage of the older adult population increasing and two-thirds of them are living in small communities, the role of intercity buses in flourishing, with services to older residents unprecedented. In a time where various data sources indicate that the low income groups are expanding, intercity buses could be a viable choice for those who are less fortunate and do not own a car. Intercity bus is a better alternative form of transportation that is significantly less expensive than driving. In a broader sense, if the future requires the creation of a community that sustains itself, an intervention area will need to be creating a sustainable transportation system. To this end, intercity buses could be a promising mode of travel in terms of social, economic, and environmental advantages over other intercity modes. Any effort to create a "less driving" society should encourage intercity buses, along with other intercity travel modes, to reduce fuel consumption and global warming pollution. 
Table 2. Summary of Intercity Transportation in Terms of Sustainability Indicators

\begin{tabular}{|c|c|c|c|c|c|}
\hline The Three E's & Indicators & $\begin{array}{l}\text { Intercity } \\
\text { Bus }\end{array}$ & $\begin{array}{c}\text { Rail/ } \\
\text { Amtrak }\end{array}$ & $\begin{array}{l}\text { Air } \\
\text { Service }\end{array}$ & $\begin{array}{l}\text { Information } \\
\text { Sources }\end{array}$ \\
\hline \multirow{2}{*}{ Economic } & $\begin{array}{l}\text { Subsidy per passenger mile } \\
\text { (1996-2005) }\end{array}$ & $\begin{array}{c}\$ 0.1 \\
(2005 \\
\text { dollars) }\end{array}$ & $\begin{array}{c}\$ 19.2 \\
(2005 \\
\text { dollars) }\end{array}$ & $\begin{array}{c}\$ 0.5 \\
(2005 \\
\text { dollars })\end{array}$ & $\begin{array}{c}\text { Nathan } \\
\text { Associates } 2008\end{array}$ \\
\hline & $\begin{array}{l}\text { Passenger out-of-pocket } \\
\text { cost }\end{array}$ & Lower & low & high & NA \\
\hline \multirow{3}{*}{ Environment } & Passenger mile per gallon & 200 & 70 & 48 & $\begin{array}{l}\text { M. J. Bradley \& } \\
\text { Associates } 2008\end{array}$ \\
\hline & $\begin{array}{l}\text { Energy (BTU) per passen- } \\
\text { ger mile }\end{array}$ & 600 & 2100 & 3200 & $\begin{array}{l}\text { M. J. Bradley \& } \\
\text { Associates } 2008\end{array}$ \\
\hline & $\begin{array}{l}\mathrm{CO} 2 \text { emissions (grams per } \\
\text { passenger mile) }\end{array}$ & 50 & 180 & 230 & $\begin{array}{c}\text { M. J. Bradley \& } \\
\text { Associates } 2008\end{array}$ \\
\hline \multirow{3}{*}{ Equity } & $\begin{array}{l}\text { Service to rural communi- } \\
\text { ties (\% of rural communi- } \\
\text { ties using service) }\end{array}$ & $89 \%$ & $42 \%$ & $71 \%$ & USDOT; BTS 2005 \\
\hline & $\begin{array}{l}\text { Service to low income } \\
\text { groups (\% of users with an- } \\
\text { nual salary of }<\$ 25,000 \text { ) }\end{array}$ & $54.2 \%$ & $22.6 \%$ & $9.7 \%$ & $\begin{array}{c}\text { American Travel } \\
\text { Survey } 1995\end{array}$ \\
\hline & $\begin{array}{c}\text { Safety (passenger fatalities } \\
\text { per billion passenger miles } \\
\text { b/n 1999-2008) }\end{array}$ & 0.3 & 1.4 & 0.9 & Damuth 2008 \\
\hline
\end{tabular}

\section{References}

Bourquin, Paul. 2008. Motorcoach Census 2008: A bench $\neg$ marking study of the size and activity of the motorcoach industry in the United States and Canada in 2007. Nathan Associates for the American Bus Association.

Bureau of Economic Analysis. "Travel and tourism data files 1998-2007." http:// www.bea.gov/industry/tourism_data.htm.

Bureau of Transportation Statistics. 2005. Scheduled intercity transportation:

Rural service areas in the United States. U.S. Department of Transportation, Research and Innovative Technology Administration (RITA).

Bureau of Transportation Statistics. 2012. The Intermodal Passenger Connectivity Database. U.S. Department of Transportation, RITA. 
Damuth, Robert. 2008. The economic impacts and social benefits of the U.S. motorcoach industry: Binding the nation together by providing diverse and affordable services to everyone. Nathan Associates, Revised Draft.

Damuth, Robert. 2011. Federal subsidies for passenger transportation, 1960-2009: Focus on 2002-2009. Nathan Associates, Inc.

Federal Transit Administration (FTA). 2007. FTA Circular 9040.1F. Federal Transit Administration, Washington, D.C.

Fravel, Frederic D. 2003. Intercity Bus Links: Moving into New Territory. TR News 225.

Guerrilla Economics, LLC. 2007. The economic impact of motorcoach tourism in Southwestern Pennsylvania. American Bus Association Foundation.

Guerrilla Economics, LLC. 2007. The economic impact of motorcoach tourism in West Virginia. American Bus Association Foundation and West Virginia Division of Tourism.

Kack, David, Zhirui Ye, Jaydeep Chaudhari, and Levi Ewan. 2011. Montana intercity bus service study. FHWA/MT-11-005/8211.

KFH Group, Inc. 2007. California statewide rural intercity bus study. California Department of Transportation, Sacramento.

Klein, Nicholas J. 2011. More than just a bus ride: Curbside intercity buses. Paper presented at the 90th TRB Annual Conference.

McKone, Jonna. 2011. America's fastest growing form of transit: The intercity bus. TheCityFix.

M. J. Bradley \& Associates. 2011. Updated comparison of energy use \& emissions from different transportation modes. American Bus Association.

O'Toole, Randal. 2011. Intercity buses the forgotten mode. Policy Analysis No. 680, CATO Institute.

Schwieterman, Joseph P., Lauren Fischer, Sara Smith, and Christine Towles. 2007. The return of the intercity bus: The decline and recovery of scheduled service to American cities, 1960-2007. School of Public Service Policy Study, DePaul University. 
Schwieterman, Joseph P. 2010. The intercity bus: America's fastest growing transportation mode: 2010 update on scheduled bus service. School of Public Service Policy Study, DePaul University.

Schwieterman, Joseph P., Lauren Fischer, Caitlin Ghoshal, Paige Largent, Nicole Netzel, and Marisa Schulz. 2011. The intercity bus rolls to record expansion: 2011 update on scheduled motor coach service in the United States. School of Public Service Policy Study, DePaul University.

Transportation Research Board. 2002. Effective approaches to meeting rural intercity bus transportation needs. TCRP Report 79.

Wrenick, Frank E. 2011. The Streamline Era Greyhound Terminals: The Architecture of W. S. Arrasmith. Jefferson, North Carolina: McFarland Publishing.

\section{About the Author}

Dr.Mintesnot G. Woldeamanuel (mintesnot.woldeamanuel@csun.edu) is an Assistant Professor in the department of Urban Studies and Planning at California State University Northridge. Prior to joining Cal State Northridge, he worked as an Assistant Professor in the Planning and Community Development Program of Saint Cloud State University and as a Research Fellow at the Transportation Research Institute of German Aerospace Center (DLR). His research interests includes urban transportation planning, land use, travel behavior analysis, community development, and sustainability. 